\title{
Organic Farming in Bangladesh: To Pursue or not to Pursue? An Exploratory Study Based on Consumer Perception
}

\author{
Rubaiya Murshed ${ }^{1}$ and Mohammad Riaz Uddin ${ }^{2 *}$ \\ ${ }^{1}$ Department of Economics, University of Dhaka, Dhaka, Bangladesh \\ ${ }^{2}$ Bangladesh Institute of Development Studies (BIDS), Dhaka, Bangladesh \\ * Corresponding author: E-Mail: rubaiyamurshed@gmail.com; rubaiya@du.ac.bd
}

Submitted: 24 May 2018 | In revised form: 18 November 2019 | Accepted: 17 February 2020 |

Published: 28 April 2020

\begin{abstract}
The development of organic agriculture in Bangladesh has been slow. According to the Bangladesh Bureau of Statistics (2018), approximately 12,000 farmers in Bangladesh produce organic crops on around 7,000 hectares of land. The transition from conventional to organic farming has been an issue of debate, especially in the context of developing nations such as Bangladesh. The debate stresses the urgency for the transition to preserve environment and health and to ensure a safe, sustainable and environmentally friendly food production system, but also emphasizes the pressure of maintaining food production for a large growing population. We focus on the debate in the context of Bangladesh, and question whether it is the proper time and stage in the development process to attempt the transition from conventional to organic food production systems. We ask why the organic rice market is not expanding in Bangladesh and explain the slow market growth through the two main factors of income constraint and lack of awareness among people about the environmental and health detriments of non-organic farming. The exploratory study finds that it is not mainly the lack of awareness but the income constraint that can be principally attributed to the slow expansion of the organic rice market in Bangladesh. Through exploring consumers' awareness about organic farming methods and their demand for organic products, this study shows how income as a major constraint, besides price, affects consumers demand for organic and non-organic rice in Bangladesh. Income being identified as the major barrier reveals the potential of the organic rice market to grow in the future, as Bangladesh continues its journey towards becoming a middle-income country.
\end{abstract}

Keywords: agriculture; consumer income level; consumer perception; food production; organic rice; primary data; survey data analysis

\section{Introduction}

Agricultural food production methods have evolved over time with the advancement of technology. These methods may vary across countries, climates and geographical locations. The debate circling the transition from conven- tional food production methods to organic food production systems has been a universally researched issue. Food production methods that involve the use of chemical fertilizers and pesticides are referred to as 'conventional' [1]. Although there are controversies regarding the magnitude of the negative effect $[2,3]$, the increased use of 
chemical fertilizers and pesticides leads to environmental degradation (such as decline in soil productivity, contamination of water bodies), and adversely affects the ecosystem (aquatic life, livestock etc.) and human health [4-16]. There is a growing need for a sustainable agricultural system which is not harmful [17]. Yunlong and Smith [18] suggest that the sustainability of an agricultural system should be assessed from 'the perspectives of ecological soundness, social acceptability, and economic viability'. An alternative to conventional agriculture is 'organic agriculture', which emphasizes the reduced use of agro-chemicals, and promotes the increased use of local, natural, organic and on-farm resources in order to make the agricultural system ecologically, economically and socially more sound and sustainable than conventional agriculture [19-21]. Organic farming methods usually avoid the high dosage of chemical pesticides, chemical artificial fertilizers, genetically modified organisms, man-made fertilisers, antibiotics, growth hormones and livestock feed additives used in conventional farming methods [22-24]. In this study, the term 'organic' is referred to as a system in which artificial chemical pesticides and fertilizers are generally avoided in crop production or used in a minimum amount compared to the amount used in conventional agriculture.

In Bangladesh, the transition between conventional and organic farming involves the consideration of food security and the differences between the two food production methods. Farmers are not likely to quickly shift to organic agricultural methods because their financial return is higher in conventional agriculture. Moreover, crop production and food supply is the farmers' prime concern due to the focus on attaining food security [20]. In Bangladesh, increased crop production has been incentivized by providing subsidies for intensified usage of chemical fertilizers, pesticides and irrigation equipment [25].

Conventional and organic agricultural systems in Bangladesh differ in the usage, specifically in the dosage, of chemical fertilizers. Majority of organic farmers in Bangladesh apply some minimal amount of chemical fertilizers, but since their amount of usage is significantly lower than the amount used by conventional farmers, they are considered to be using organic agricultural methods $[9,10,20,26]$. On the contrary, very few farmers in more organic agricultural systems apply chemicals to crops because they use their 'indigenous knowledge' to control insects by using herbal natural pesticides and traps. Thus, the organic agricultural system is less dependent on chemical inputs compared to the conventional system [20,27].

Research has been conducted to verify whether using a more organic agriculture system might reap benefits in Bangladesh. Rasul and Thapa [20] found that organic agriculture does not differ much from conventional agriculture in terms of land-use patterns, crop yields and food security, and that there is no significant difference in financial and economic benefits, and in value addition. The study sug- gests that without alternative cost-effective ways of maintaining crop yields, farmers would find it difficult to reduce and abandon the use of chemicals in crop production.

Moreover, while the global organic food market is growing $[28,29]$, organic farming still occurs mostly on an experimental basis in Bangladesh. Organic cultivation in Bangladesh is estimated at 0.177 million hectares [28], representing only $2 \%$ of the country's total cultivable land. According to the IFOAM Annual Report [28] (2010), out of the 138 NGOs that are members of the Forum of Regenerative Agriculture Movement (FORAM) in Bangladesh, only 47 are engaged in organic agriculture. There are only a few commercial organic crop suppliers in the capital city Dhaka- Proshika, Kazi Shahid Foundation, Meena Bazar and Shoshya Probortona. To attain food security, conventional food production methods have been the sought solution for Bangladeshi policymakers since the nation's independence. For example, rice has been produced through 'genetically modified' food production methods to attain food security. Many varieties of rice, such as 'Golden rice' [30], has thus gained recognition in the process [31]. However, soon after the recognition of these brands of rice, the criticism of genetically modified food production processes arose [32]. Scepticism also arose on how food security could be compromising the nutrition status of people [33]. Since farmers often lack the knowledge about the correct dosage and usage of pesticides in farming, the risk of damages from pesticide and chemical fertilizer based genetically modified conventional food production methods could be higher [34].

This research explores the reasons behind the slow growth of the organic rice market size in Bangladesh. Perhaps most consumers are still not much concerned about the health effects of chemicals-based product and organic agriculture might become economically viable in the future if health-conscious people are willing to pay higher prices for organic crops [20]. According to the Kazi Shahid Foundation [35], the main reasons for organic farming not expanding in Bangladesh are the lack of support from the government and citizens' lack of awareness.

In understanding the demand for a particular product, the factors usually taken into consideration include the price of the product, the price of substitute products, income of the consumers, purchasing power of the consumers, awareness of the consumers about the products and advertising of the product [36]. This research aims to understand whether the income constraint of consumers, alongside consumers lack of awareness about organic production methods, is contributing to the rigidity of the organic rice market growth in Bangladesh. In theory and in reality, the price of organic products in the food market is usually higher than the same products produced conventionally, mainly because of the higher costs associated with organic production [37]. We hypothesize that consumers' income constraint is the main reason behind the slow growth of the organic rice market in Bangladesh, and that the market will not thrive unless consumers' income 
level increases.

If this is true, it could lead to the contemplation of whether pursuing organic rice production methods on a large scale in Bangladesh is appropriate at the current stage of development where, according to World Bank [38], the GDP per capita of Bangladesh was USD 1,827 in June, 2019 after an increase from 1,675 USD in 2018. With the middle-income country goal looming on the horizon, perhaps organic food production would be a more viable route to pursue in the near future once the income goal is reached. Previous research has indicated consumers' low income level to be a barrier to organic production, especially in poorer countries [39]. Moreover, market opportunities offer insufficient incentives for practicing organic agriculture in low income countries. On the other hand, Willer and Yussefi [29] argued that organic agriculture can be advantageous for poorer countries through contributing to purposeful and sustainable socio-economic and ecological development. Additionally, if consumers are unaware of better substitutes to conventional products and lack information about the availability of organic products, perhaps many consumers with the willingness to purchase the products, and the affordability, would miss the opportunity to purchase [40].

This study considers the possibility of consumers' lack of awareness being a strong reason behind the stiff growth of the organic rice market in Bangladesh. Several studies have highlighted the environmental awareness and health consciousness of consumers as major determinants to their shifting from conventional products to organic products $[2,41,42]$.

This research analyses the demand for organic food by consumers in Dhaka, Bangladesh. The objectives of this research are: (1) Testing the awareness level of local consumers in Dhaka city about organic food products, (2) Identifying the preference criteria of organic and conventional food consumers in Dhaka, which would reveal what factors are considered by consumers who choose between these two types of food products, (3) Testing the hypothesis that income is a major barrier to consumers' organic food consumption. This research is explorative in nature so the findings may not be generalizable from the sample to the population, but may stimulate the need for further research on the topic.

\section{Material and Methods}

\subsection{Data Collection}

The data was collected, through person-to-person interaction instead of through online platforms, from grocery stores where organic food products are regularly available alongside conventional food products. The two main organic food product selling stores in Dhaka city are Meena Bazar and Shoshya Probortona. Data was collected from consumers shopping in these two stores during the period of 8 to 11 August 2012, thereby including consumers of both organic and conventional food products and capturing different income levels among the consumers. A questionnaire was designed to collect the data and the consumers were requested to spare 15 minutes of their grocery-shopping time to fill in the survey face-to-face with the researcher. Some consumers preferred filling in the questionnaire themselves and talked to the researcher about their answers through the process. Consumers participating in the survey were given a $5 \%$ discount by the stores. Data was collected from 120 consumers. The questionnaire consisted of both closeended and open-ended questions. Data on consumers' awareness and perception was collected through a mixture of dichotomous questions, importance questions, buying propensity questions and matrix questions. Data for the econometric analysis was collected through open-ended questions, e.g. about households' monthly income, monthly expenditure etc.

Although the sample size for the study was 120 , it shrank to 70 for the econometric analysis because of missing values in the respondents' answers. This small sample size means findings are not representative of and not generalizable to the target population which is organic rice consumers in Dhaka, so, this study is exploratory in nature, aiming to provide grounds for further research to verify the highlighted aspects.

The respondents were randomly chosen from the stores that are the most popular in terms of supplying organic food and drink items in Dhaka. Since we aimed to collect evidence from more informed (about organic products) people, we believe that there is no sample bias because of the assumption that most organic food shoppers may usually go to the surveyed organic shops for their organic purchases. For the same reason, in the case of the descriptive statistics analysis, artificial positively induced answers are not believed to be a problem in this study. The short duration of the survey is the main limitation of this study but two of the main organic rice supplier shops in Dhaka were covered by the survey.

\subsection{Methods of Analysis}

The collected data was used for two types of analysis: (1) To present descriptive statistics reflecting the consumers' perceptions and awareness about organic food products, and (2) To estimate a regression model testing the hypothesis stated in this research that income is a major constraint in consumers' demand for organic rice. The regression model was estimated using STATA, and included variables depicting consumers' demand for organic rice, price of organic and conventional rice, environmental awareness, health consciousness, quality satisfaction, family size and household income. Environmental awareness, health consciousness, quality satisfaction etc. are factors that could potentially affect consumers' demand for organic food products $[39,43]$. In the case of the price of rice, a weighted price of rice was calculated with the particular amount of quantity demanded used as the weight. 


\subsection{Econometric Model}

The econometric model is based on a multiple variable regression equation (OLS method).

In (Average quantity demanded of organic rice by consumer) $=\alpha+\beta_{1} \ln$ (Monthly Household Income) $+\beta_{2}$ ln (Average quantity demanded of conventional rice by consumer) $+\beta_{3}$ ln (Average weighted price of organic rice) $+\beta_{4} \ln$ (Average weighted price of conventional rice) $+\beta_{5}$ Environmental awareness dummy variable $+\beta_{6}$ Education level dummy variable $+\beta_{7}$ Health consciousness dummy variable $+\beta_{8} \ln$ (Family size) $+\beta_{9}$ Quality Satisfaction dummy variable + error

The variables in the model follow from the basic 'Law of Demand' of Economics, which states that demand for a good is inversely related to its price. The other factors affecting demand include income, consumer's preference etc. The variables 'Environmental awareness', 'Health consciousness', 'Quality satisfaction' have been included in the model, in the form of dummy variables, based on the assumption that these influence consumer's preference towards organic foods.

The econometric model was tested on the basis of 'goodness of fit' by the R2 method. The VIF tolerance method was used to test the existence of multicollinearity; the Breusch-Pagan test was used to test the existence of heteroscedasticity, and the Ramsey RESET (Regression Specific Error Test) was used to test specification bias in the model.

\section{Results and Discussion}

\subsection{Socio-economic Status}

According to the respondents' income distribution, three income levels were identified, monthly income (1) $<12,000$ taka, (2) 12,000 taka to 75,000 taka and (3) $>75,000$ taka. The floor and ceiling were chosen to capture the median of the income distribution based on the sample. Among the respondents, $77.5 \%$ fell under the middle income group, which indicates a middle-income bias in the data, while $5.8 \%$ and $16.7 \%$ were in the highest and lowest income bracket, respectively. This indicates that the two grocery stores where the survey was conducted are reasonably affordable places for lower-middle class, middle class, and higher middle class and upper class people, to shop for daily groceries, such as rice. Usually, class categories are classified based on income status and living conditions of consumers.

\subsection{Environmental and Health Awareness}

Approximately $3.3 \%$ of the respondents are moderately aware about what harms the environment and how to preserve the environment; and $96.7 \%$ of the respondents are very aware (Figure 1). In this case, environmental awareness was measured by asking the respondents questions (framed in a 'Likert scale' structure) about the environment, pollution, green farming etc. and the respondents' answers to the questions were categorized into high, medium, low awareness groups. Most of the respondents stated that they knew about organic food, the threats of conventional food to the environment, and the environmental benefits of organic farming.

Around $2.5 \%$ of the respondents are moderately conscious of what affects their health positively and negatively; and most of the respondents (97.5\%) are very conscious of their health (Figure 2). Health consciousness was measured by asking the respondents questions (framed in a 'Likert scale' structure) about smoking, healthy dieting, exercise etc. and especially about their views on what types of food are harmful for their health. The respondents were specifically probed about their concern about how non-organic food could be affecting their health. The respondents' answers were categorized into three levels of consciousness.

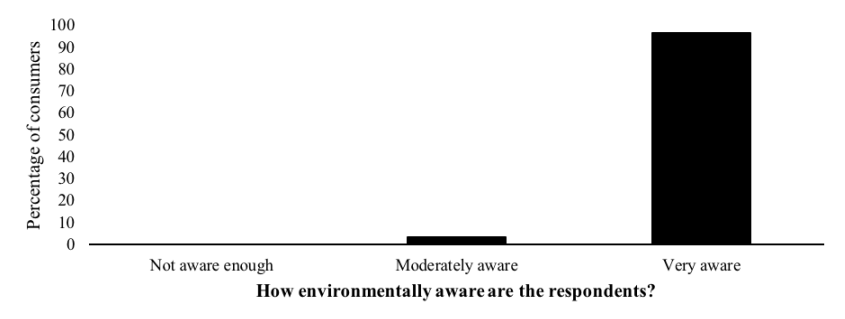

Figure 1. Environmental awareness of the consumers, percentage of respondents $(n=120)$.

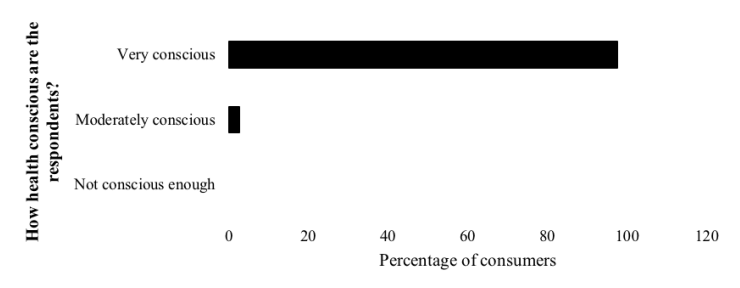

Figure 2. Health consciousness of consumers' $(n=120)$.

\subsection{Other Factors and Aspects}

Most consumers (88 out of 120) understand organic food to be products produced without chemical pesticide usage; while 21 out of 120 consumers perceive organic food to be natural food made with natural unprocessed ingredients (Figure 3). This portrays that although most respondents are aware of the basic concept of organic foods, perhaps their understanding of the term could be clearer, especially in terms of the methods used in producing the organic food products. 
Around $97.5 \%$ of the respondents (117 out of 120 respondents) are willing to purchase certified organic foods even if it costs them more than purchasing the alternate conventional versions of the products (Table 1). The three consumers who responded that they would not be willing to purchase organic food items at higher prices were found to be in the lower income group. This indicates that income constraint may negatively affect the consumers' willingness to purchase organic food items.

Approximately $77.5 \%$ (93 of the 120 ) of the respondents spend 10,000-20,000 taka per month on food products, while $16.7 \%$ of the respondents (20 out of 120 ) spend $>20,000$ taka per month on food, and only $5.8 \%$ (7 out of 120 ) of the respondents' monthly food expenditure is $<10,000$ taka. Although these figures seem coherent with the income distributions of the three income level groups in this study, monthly food expenditure does not depend on income alone, but also depends on household size. So, respondents' monthly food expenditure cannot be linked with the income groups alone without data of how many people each of the respondents' buy food for. Table 2 shows some important patterns nonetheless (1) Out of the 20 respondents whose monthly food expenditure is comparatively high ( $>20,000$ taka per month), 15 respondents $(75 \%)$ confirmed that they purchase organic food products instead of conventional ones regularly while regular purchase of organic items in the total sample was observed for only $43.3 \%$ of the respondents. Thus, there seems to be a positive relationship between monthly food expenditure and purchasing organic food products.

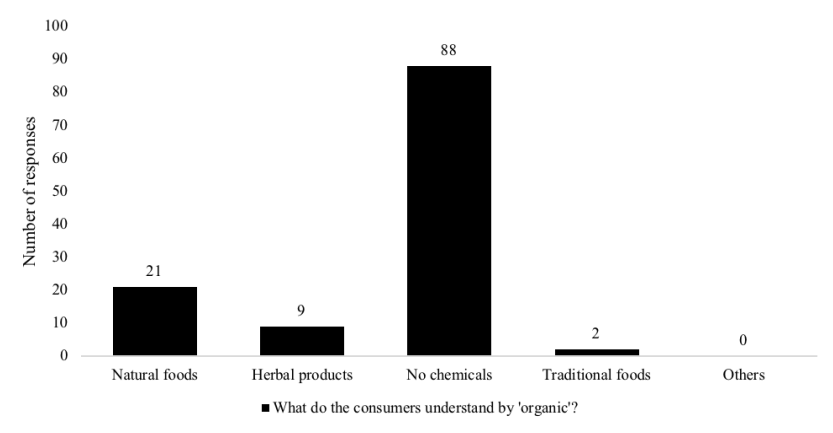

Figure 3. Consumers' understanding of the term 'organic food' $(n=120)$.

Table 1. Cross-tabulation of consumers' income status and their willingness to pay more for certified organic foods $(n=$ 120).

\begin{tabular}{|c|c|c|c|c|c|}
\hline \multicolumn{6}{|c|}{ Income Status of the Consumers } \\
\hline & & $\begin{array}{l}\text { Below } \\
12,000 \\
\text { taka }\end{array}$ & $\begin{array}{l}(12,000 \text { to } \\
75,000) \\
\text { taka }\end{array}$ & $\begin{array}{l}\text { Above } \\
75,000 \\
\text { taka }\end{array}$ & Total \\
\hline $\begin{array}{l}\text { Willingness } \\
\text { to pay more }\end{array}$ & $\begin{array}{l}\text { Not } \\
\text { willing }\end{array}$ & 3 & 0 & 0 & 3 \\
\hline \multirow[t]{2}{*}{$\begin{array}{l}\text { for certified } \\
\text { organic foods }\end{array}$} & Willing & 4 & 93 & 20 & 117 \\
\hline & Total & 7 & 93 & 20 & 120 \\
\hline
\end{tabular}

Table 2. Cross tabulation between consumers' purchasing status of organic items with monthly food expenses ( $n=$ 120).

\begin{tabular}{llllll}
\hline \multicolumn{5}{c}{ Consumers' organic food purchasing status } \\
\hline $\begin{array}{l}\text { Monthly food } \\
\text { expenses } \\
\text { (taka) }\end{array}$ & Regular & $\begin{array}{l}\text { Fre- } \\
\text { quent }\end{array}$ & Seldom & $\begin{array}{l}\text { Never } \\
\text { pur- } \\
\text { chase }\end{array}$ & Total \\
\hline $\begin{array}{l}\text { Below } 10,000 \\
10,000-\end{array}$ & 0 & 0 & 7 & 0 & 7 \\
15,000 & 10 & 12 & 8 & 0 & 30 \\
$16,000-$ & 27 & 33 & 3 & 0 & 63 \\
20,000 & 5 & 5 & 0 & 0 & 10 \\
$21,000-$ & 6 & 0 & 0 & 0 & 6 \\
25,000 & 4 & 0 & 0 & 0 & 4 \\
$26,000-$ & 52 & 50 & 18 & 0 & 120 \\
\hline $\begin{array}{l}\text { Above } 30,000 \\
\text { Total }\end{array}$ & 5000 & & & \\
\hline
\end{tabular}

Approximately $48.3 \%$ of the respondents' (58 out of 120 of the respondents) came to know about organic food products from advertises on television and from TV programs promoting organic food production (health shows, talk shows on health and environment etc.); and 27.5\% (33 out of 120) of the respondents learnt about organic food items from newspaper reviews, articles and advertises (Figure 4). Respondents who said that they had learnt about organic food from TV programs were asked to mention specific TV programs and channels they had watched in learning about organic food; and all of the respondents' answers revealed that the shows had been on international channels rather than on national TV channels. Thus, the different medias that can be used in spreading awareness about organic foods can be researched more to reach a wider audience in Bangladesh.

Around $80 \%$ (96 out of 120 ) of the respondents have considered consuming organic foods but haven't consumed (all 96 of the respondents indicated the reason behind this to be the high price of the organic products and the lack of affordability); while only $14.2 \%$ (17 out of 120 ) of the respondents have actually purchased and consumed organic foods (Figure 5).

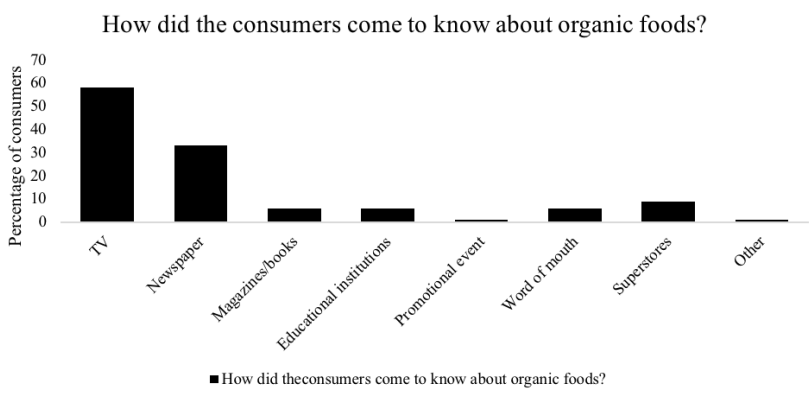

Figure 4. Consumers' source of information in learning about organic foods $(n=120)$. 
Only 7 of the 120 respondents (5.8\%) have not purchased any organic food items yet (Fig. 6); 38 out of the 120 respondents $(31.7 \%)$ have been purchasing for at least a year; and 75 out of the 120 respondents (62.5\%) have been purchasing organic food products from time to time for at least two years and more (Figure 6). The respondents who had been purchasing organic foods for at least a year or for more than one year were asked why they had made the conscious shift towards purchasing organic foods, and $97 \%$ of them responded that it was because they had realized the health benefits of the organic products and had made the shift only when they could afford to buy the organic products.

Most of the respondents (93 out of 120 respondents) prefer to buy organic food products from specific stores that they are familiar with and trust (Fig. 7); while many consumers (15 out of 120 respondents) opt for checking the labels of the food products and the company name to verify the quality and authenticity of the organic food products (Figure 7).

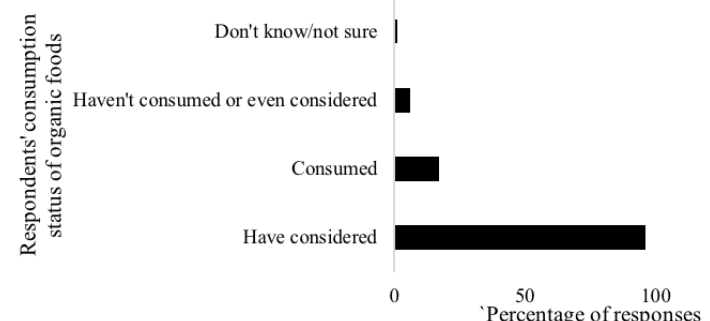

Figure 5. Whether the consumers ever consumed or considered consuming organic food $(n=120)$.

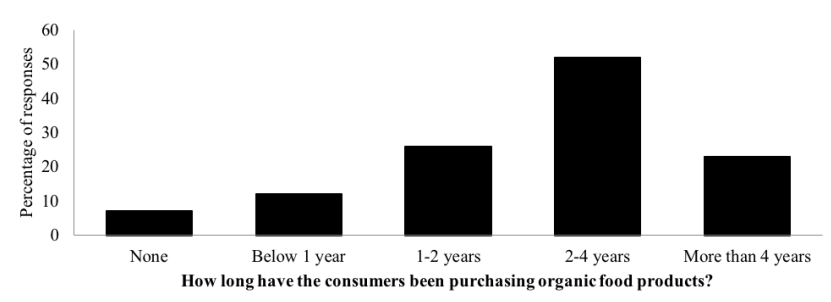

Figure 6. Consumers' time period of having been aware about organic products and having started purchasing organic food products from time to time $(n=120)$.

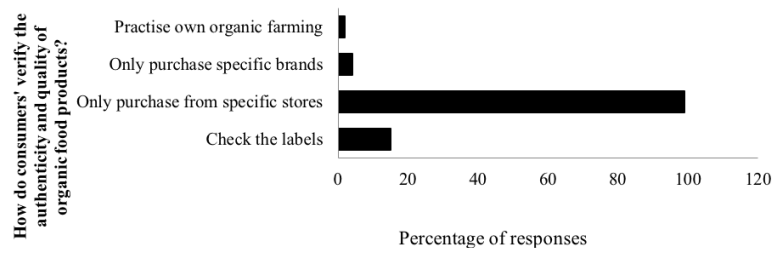

Figure 7. Consumers' organic food products verifying system $(n=120)$.
Around $90.8 \%$ of the respondents (109 out of 120 respondents) think that the government should be responsible for verifying the quality and authenticity of the organic food products (Figure 8). Consumers' perceptions on issues like such verifications are very important for the growth of the organic food market, because these are the issues that the authorities and suppliers would have to take into account to maximize their business opportunities, supplies and profits in the organic food market.

Approximately $77.5 \%$ of the respondents (93 out of 120 ) have purchased and consumed organic food products because of the products being environmentally friendly, and this indicates that the respondents of the survey in this research are quite concerned about conserving the environment (Figure 9). So, there seems to be little to no lack of awareness among the respondents about the environmental benefits of organic food products, and this could rule out lack of awareness as a reason behind these consumers' not purchasing organic food products.

Around $80.83 \%$ of the respondents (97 out of 120 ) would be willing to pay $0-9 \%$ premium price, meaning that they would be willing to pay a maximum of $9 \%$ more than the price of conventional rice to purchase organic rice (Figure 10 ). Moreover, $19.17 \%$ of the respondents (23 out of 120 ) said that they would be willing to pay over $9 \%$ premium price, and even up to $39 \%$ in case of some of the respondents for organic rice instead of conventional rice. The respondents who were willing to pay $20 \%$ or over $20 \%$ price premium were in the high income status groups (Monthly income $>75,000$ taka).

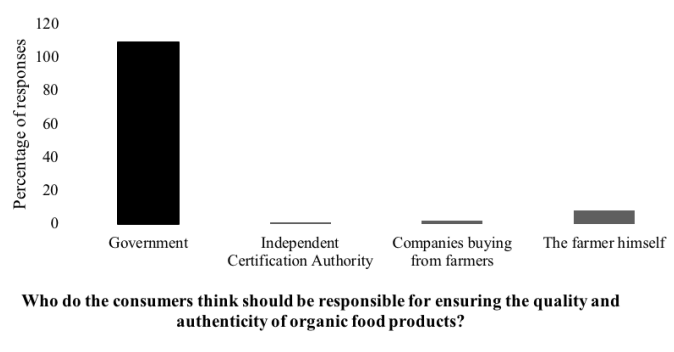

Figure 8. Consumers' perception about responsibility of verification.

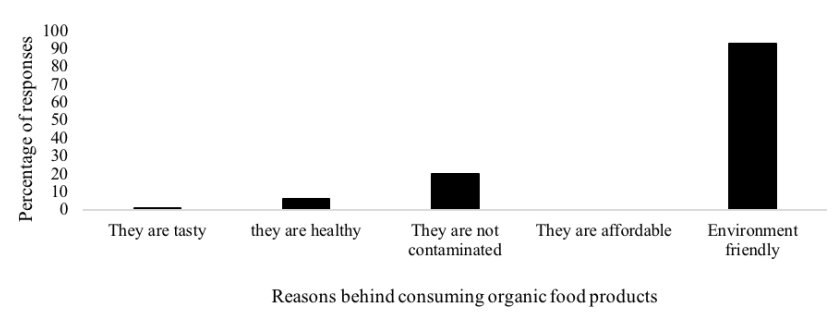

Figure 9. Consumers reasons for purchasing and consuming organic food products $(n=120)$. 
The quality of the organic food products is the most popular characteristic that attracts the respondents to purchase organic food products. Around $71.7 \%$ of the respondents stated quality to be the most persuading characteristic that pulls them towards consuming green products (Figure 11). This is a signal to authorities of organic food supply chains to ensure the quality of organic products in order to meet the demand criteria of the consumers of the organic food market.

Figure 12 shows that vegetables are the most popular (51 out of 120 respondents) organic food followed consecutively by fruits (38 out of 120 respondents); and fish (20 out of 120 respondents). This could be a reflection of the general suspicion, which has also gained widespread media coverage, about the extensive usage of harmful formalin, pesticides in fresh fruits, vegetables, and fish in Bangladesh. Food Adulteration has been a topic covered by the media extensively, which might have had an influence on consumers opting to buy organic fruits, vegetables, fish etc.

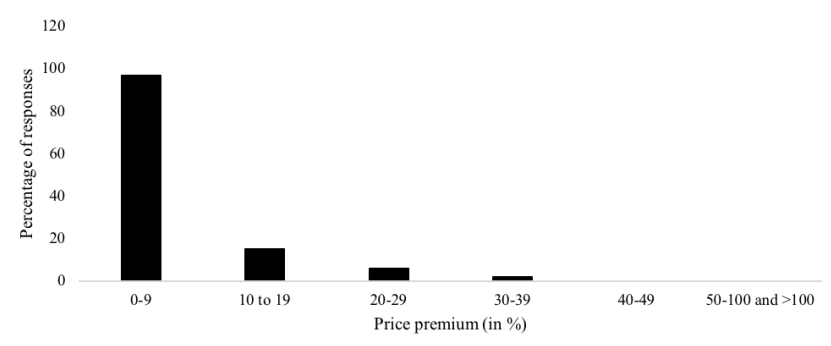

Figure 10. Premium price that consumers would be willing to pay for organic rice $(n=120)$.

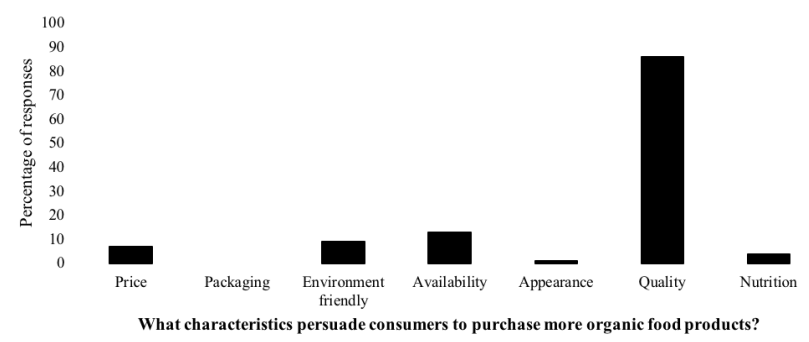

Figure 11. Characteristics that persuade consumers to buy more green products $(n=120)$.

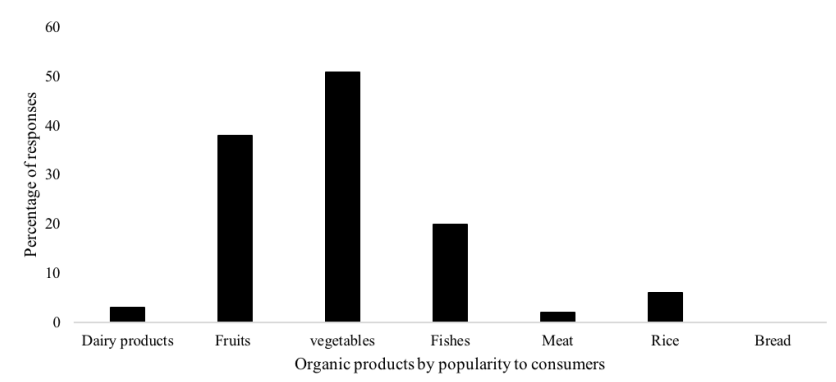

Figure 12. Ranking organic food products by popularity among consumers $(n=120)$.
Tables 3 and 4 respectively show the perceptions and problematic experiences of organic food consumers. Regarding the consumption of organic food in Bangladesh, $40 \%$ consumers' face the problem of high price; while $36.7 \%$ face the problem of insufficient supply. High price being perceived as a problem could be linked to the income constraint of consumers, indicating that income constraint could be a strong determinant in consumers' organic food purchasing.

Table 3. Cross tabulation between consumers' purchasing status of organic items with monthly food expenses ( $n=$ 120).

\begin{tabular}{|c|c|c|c|}
\hline Statement & Agreed & $\begin{array}{l}\text { Partially } \\
\text { agreed }\end{array}$ & $\begin{array}{l}\text { Not } \\
\text { agreed }\end{array}$ \\
\hline $\begin{array}{l}\text { Available organic foods in Bangladesh } \\
\text { are really organic }\end{array}$ & $\begin{array}{l}42 \\
(35 \%)\end{array}$ & $\begin{array}{l}64 \\
(53.3 \%)\end{array}$ & $\begin{array}{l}14 \\
(11.7 \%)\end{array}$ \\
\hline $\begin{array}{l}\text { Quality of the available organic foods is } \\
\text { satisfactory }\end{array}$ & $\begin{array}{l}11 \\
(9.2 \%)\end{array}$ & $\begin{array}{l}104 \\
(86.7 \%)\end{array}$ & $5(4.2 \%)$ \\
\hline Price of organic foods is very high & $\begin{array}{l}112 \\
(93.3 \%)\end{array}$ & $8(6.7 \%)$ & $0(0 \%)$ \\
\hline $\begin{array}{l}\text { Supply of organic food items in the } \\
\text { market is sufficient }\end{array}$ & $0(0 \%)$ & $\begin{array}{l}16 \\
(13.3 \%)\end{array}$ & $\begin{array}{l}104 \\
(86.7 \%)\end{array}$ \\
\hline $\begin{array}{l}\text { Number of organic shops is sufficient in } \\
\text { the city }\end{array}$ & $0(0 \%)$ & $\begin{array}{l}23 \\
(19.2 \%)\end{array}$ & $\begin{array}{l}97 \\
(80.8 \%)\end{array}$ \\
\hline $\begin{array}{l}\text { Organic foods should be certified by the } \\
\text { certifying authorities }\end{array}$ & $\begin{array}{l}10 \\
(83.3 \%)\end{array}$ & $\begin{array}{l}20 \\
(16.7 \%)\end{array}$ & $0(0 \%)$ \\
\hline $\begin{array}{l}\text { All types of food crops should be } \\
\text { cultivated organically }\end{array}$ & $\begin{array}{l}120 \\
(100 \%)\end{array}$ & $0(0 \%)$ & $0(0 \%)$ \\
\hline $\begin{array}{l}\text { Organic foods have less } \\
\text { pesticides/chemicals }\end{array}$ & $\begin{array}{l}118 \\
(98.3 \%)\end{array}$ & $2(1.7 \%)$ & $0(0 \%)$ \\
\hline $\begin{array}{l}\text { Organic farming help protect environment } \\
\text { and ecology }\end{array}$ & $\begin{array}{l}120 \\
(100 \%)\end{array}$ & $0(0 \%)$ & $0(0 \%)$ \\
\hline $\begin{array}{l}\text { Organic farming is as sustainable as } \\
\text { conventional farming }\end{array}$ & $\begin{array}{l}119 \\
(99.2 \%)\end{array}$ & $1(0.8 \%)$ & $0(0 \%)$ \\
\hline
\end{tabular}

Table 4. Problems faced by the consumers of organic products in $2012(n=120)$.

\begin{tabular}{ll}
\hline Problems & No. of consumers \\
\hline Insufficient supply of organic produce & $44(36.7 \%)$ \\
Organic foods are available in a limited number of shops & $3(2.5 \%)$ \\
Lack of trust of producers and sales personnel & $23(19.2 \%)$ \\
High price of organic produce & $48(40 \%)$ \\
Others & $0(0 \%)$ \\
\hline
\end{tabular}

\subsection{Findings from the Regression Analysis}

\subsection{Discussion of the Regression Results}

The regression results in Table 5 show that the average quantity demanded of organic rice increases by approximately $0.6 \%$ when the consumer's income increases by $1 \%$. The R2 value shows that approximately $72 \%$ of the variation in average quantity demanded of organic rice is explained by the independent variables incorporated in the model. There is no multicollinearity in this model, and no heteroscedasticity. The Ramsey RESET test shows that the model has no specification bias. 
The environmental awareness dummy = 1 indicates that the consumers are environmentally aware. The results show that the average quantity demanded of organic rice by aware consumers is $53 \%$ greater than that of unaware consumers'. Similarly, health consciousness dummy $=1$ indicates that the consumers are health conscious; while the results show that conscious consumers' average quantity demanded of organic rice is around $36 \%$ greater than that of unconscious consumers'. The regression results show that the 'average quantity demanded of organic rice' by consumers is largely affected by the consumer's income, besides the prices of organic rice and the substitute conventional rice. Environmental awareness and health awareness don't impact the change in consumers' demand as much as income does. Most importantly, the coefficients for 'Environmental awareness' and 'Health consciousness' are not statistically significant. In this regression model, the coefficients of 'consumers' income', 'average quantity demanded of conventional rice', 'average weighted price of organic rice' are statistically significant at the $5 \%$ significance level and the coefficient of 'Quality Satisfaction' is significant at the $10 \%$ significance level. The regression results provide proof that income level and price are two of the most important factors that influence consumers' average quantity demanded of organic rice in this regression model.

The positive relationship between 'average quantity demanded of organic rice' and 'average weighted price of organic rice' is interesting since it reflects the preferences of a consumer group that is so conscious about consuming organic rice that a rise in price does not reduce their demand for it, but rather raises it. Thus, organic rice in this analysis can be perceived as a 'Giffen good'. The positive relationship between 'average quantity demanded of organic rice' and 'average quantity demanded of conventional rice' indicates that these two goods are complementary goods in this case. Another interesting anomaly perceived in the results is the negative relationship between average quantity demanded of organic rice and the education level (dummy variable).

The upward-sloping line in Figure 13 confirms that there is a positive relationship between the variables 'average quantity demanded of organic rice' and 'income'. The important issue here is whether this relationship is stronger in magnitude than the relationships of average quantity demanded of organic rice with other factors.
Table 5. Regression Results.

\begin{tabular}{|c|c|c|c|c|c|}
\hline Source & ss & Df & Not agreed & \multicolumn{2}{|c|}{$\begin{array}{l}\begin{array}{l}\text { Number of } \\
\text { observations }=70\end{array}\end{array}$} \\
\hline Model & 20.376 & 9 & 2.264 & \multicolumn{2}{|c|}{$F(9,48)=13.39$} \\
\hline Residual & 8.118 & 48 & 48.169 & \multicolumn{2}{|c|}{ Probability $>F=0.00$} \\
\hline Total & 28.495 & 57 & 57.499 & \multicolumn{2}{|c|}{ R-squared $=0.72$} \\
\hline & & & & \multicolumn{2}{|c|}{ Adjusted R-squared $=0.66$} \\
\hline & & & & \multicolumn{2}{|c|}{ Root MSE $=0.41$} \\
\hline \multicolumn{2}{|c|}{ Organic rice demand $(l n)$} & Coefficient & $\begin{array}{l}\text { Standard } \\
\text { Error }\end{array}$ & $t$ value & $P$ value \\
\hline \multicolumn{2}{|c|}{$\begin{array}{l}\text { Consumer's } \\
\text { income }(l n)\end{array}$} & 0.618 & 0.118 & 5.23 & $0.000^{*}$ \\
\hline \multicolumn{2}{|c|}{$\begin{array}{l}\text { Conventional rice } \\
\text { demand }(l n)\end{array}$} & 0.314 & 0.104 & 3.02 & $0.004^{*}$ \\
\hline \multicolumn{2}{|c|}{ price $(l n)$} & 1.858 & 0.877 & 2.12 & $0.039^{*}$ \\
\hline \multicolumn{2}{|c|}{$\begin{array}{l}\text { Conventional rice } \\
\text { price }(l n)\end{array}$} & 1.154 & 0.826 & 1.40 & 0.169 \\
\hline \multicolumn{2}{|c|}{ Family size $(l n)$} & 0.772 & 0.513 & 1.51 & 0.139 \\
\hline \multicolumn{2}{|c|}{ Environmental } & 0.528 & 0.396 & 1.33 & 0.189 \\
\hline \multicolumn{2}{|c|}{$\begin{array}{l}\text { Education level } \\
\text { (dummy) }\end{array}$} & -0.488 & 0.409 & -1.19 & 0.238 \\
\hline \multicolumn{2}{|c|}{ Health } & 0.3645 & 0.394 & 0.93 & 0.359 \\
\hline \multicolumn{2}{|c|}{$\begin{array}{l}\text { Quality } \\
\text { satisfaction (dummy) }\end{array}$} & 0.492 & 0.273 & 1.80 & $0.078^{* *}$ \\
\hline \multicolumn{2}{|c|}{ Constant } & -18.33688 & 2.989109 & -6.13 & 0.000 \\
\hline
\end{tabular}

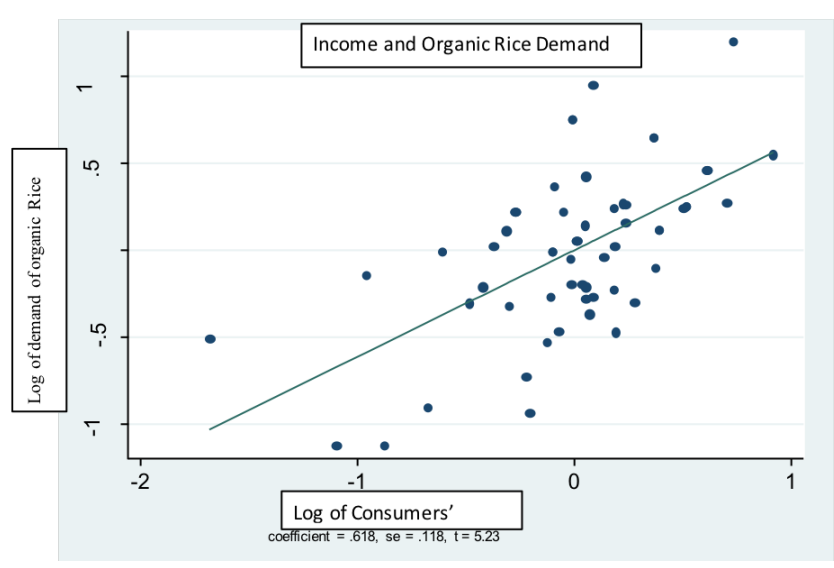

Figure 13. Relationship between average quantities demanded of organic rice and income of consumer. 

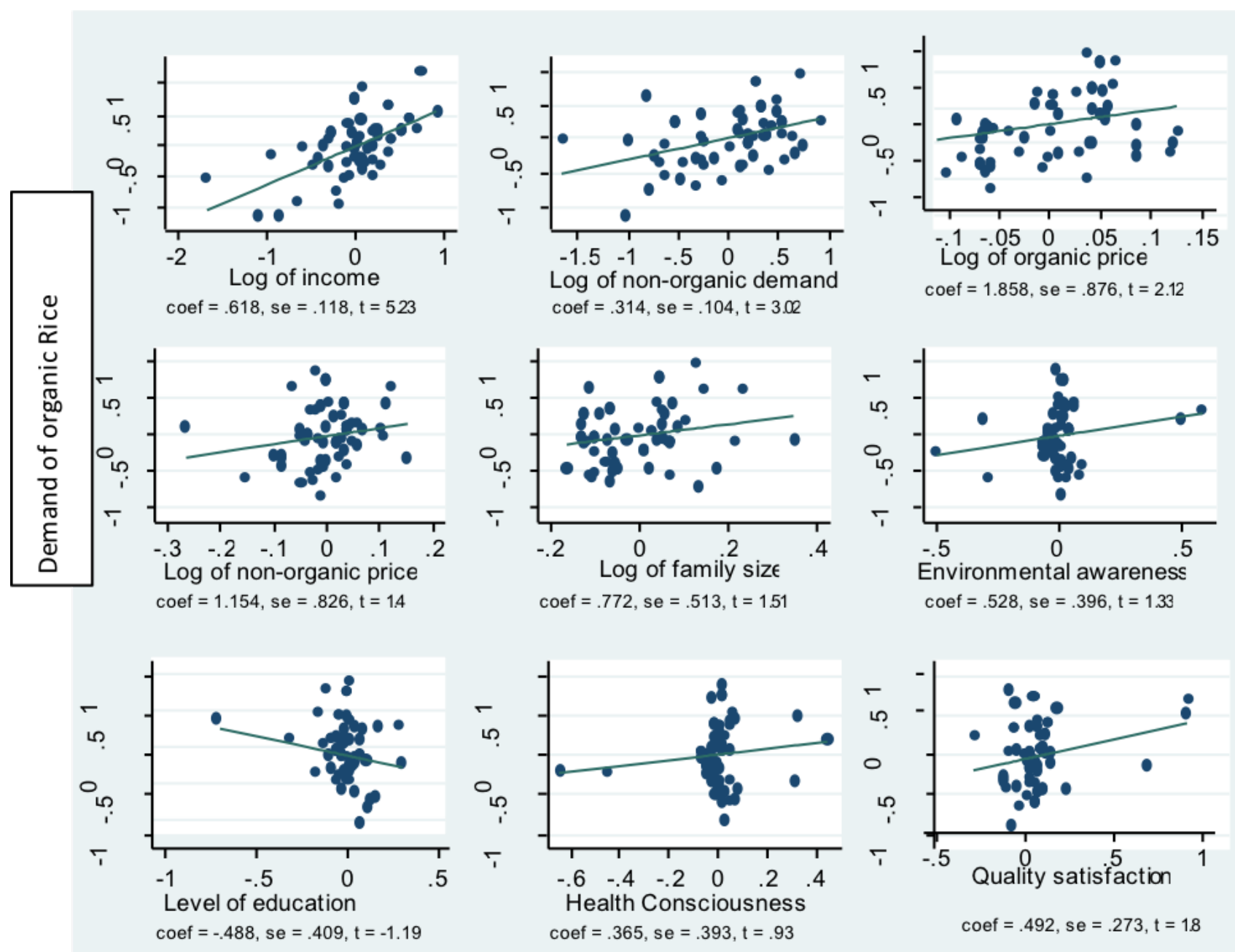

Figure 14. Comparison of slopes.

Figure 14 shows how the consumer's income is the factor that affects the average quantity demanded of organic rice the most (indicated by the steepest slope among all the graphs: the graph at the top left corner). The steeper the slope, the greater the change in average quantity demanded of organic rice due to a change in the corresponding independent variable. Considering only the variables that are statistically significant, the slopes of the graphs above indicate that consumer's income is the factor that affects the average quantity demanded of organic rice the most, which is indicated by the steepest slope among all the graphs. Thus, consumer's income is the most influencing factor in determining the average quantity demanded of organic rice by the consumers.

The results show that no matter how conscious consumers' become of the advantageous effects of organic rice on the environment and on their health- in the end, their demand and consumption is mainly controlled by the level of incomes they earn and the price of the organic products. Organic products are generally highly priced, and so the consumer's willingness to purchase organic products is mainly dependent on income.

\section{Limitations and Scope for Further Research}

This study was conducted on a small scale in Dhaka city, but the term 'in Bangladesh' has been used multiple times. To clarify, by 'in Bangladesh', we are not claiming that the results of this study are generalizable to the Bangladeshi population. The term has been used loosely to indicate that the evidence is from Bangladesh. It would be interesting to see how the findings of this study, which was based on data from consumers in Dhaka, would be in case of other cities in Bangladesh. Further, the larger the sample size, the closer the approximation of the results to reality; and the better the generalization and external validity of the data. Time constraint disallowed the sample size for this research to be any larger, and perhaps the findings could have been more significant with a larger sample size. Finally, the data collection points in this research were set according to the criteria of stores that sell organic food items alongside conventional food items. This allowed for the data to incorporate the perceptions of consumers who purchase organic food items from time to time, and also to perceive the factors consumers' base their purchasing decisions on 
when they have both the choices of organic and conventional food items available. An interesting dimension could be added to the research by incorporating the perceptions of consumers of grocery stores that do not provide organic food products.

\section{Policy Recommendations and Conclusion}

To our knowledge this research is the first of its kind in Bangladesh addressing the question of whether income constraint is the main determinant behind consumers' decisions to purchase or not purchase organic food products. The findings indicate that the shoppers in the sample have a high level of recognition for organic rice, value its benefits, are willing to pay more for it (except for shoppers earning less than $12 \mathrm{~K}$ taka) but find that it is in short supply and available at only a few markets.

The most common concern in purchasing organic foods is the cost. Organic foods typically cost more than their nonorganic conventional versions. The main reason behind the higher prices is the more expensive farming techniques and natural inputs required for the production of organic crops. If we assume that the production and supply of organic rice is determined by the demand for it, then it makes sense why the organic crop market in Bangladesh is not expanding; because market size does influence supply and production [44]. The findings suggest that consumers' demand for organic rice is mainly dependent on their income level. Our results indicate that environmental awareness and health consciousness are not as powerful determinants of consumers' demand for organic rice as income constraint. So, as long as the general average income level of the nation does not increase, the demand for and consumption of organic rice might not increase as much, despite people

\section{References and Notes}

[1] Kumari K, Kumar K, Rao CN. Adverse Effects of Chemical Fertilizers and Pesticides on Human Health and Environment. Journal of Chemical and Pharmaceutical Sciences. 2014;3:150-151.

[2] Magnusson MK, Arvola A, Hursti UKK, Ảberg L, Sjödén PO. Choice of Organic Foods is Related to Perceived Consequences for Human Health and to Environmentally Friendly Behaviour. Appetite. 2003;40(2):109-117. doi:10.1016/S0195-6663(03)00002-3.

[3] Bourn D, Prescott J. A Comparison of the Nutritional Value, Sensory Qualities, and Food Safety of Organically and Conventionally Produced Foods. Critical Reviews in Food Science and Nutrition. 2002;42(1):1-34. doi:10.1080/10408690290825439.

[4] Camargo JA, Alonso Á. Ecological and Toxicological Effects of Inorganic Nitrogen Pollution in Aquatic Ecosystems: A Global Assessment. Environment international. 2006;32(6):831-849. doi:10.1016/j.envint.2006.05.002.

[5] Scialabba N, Hattam C. Organic Agriculture, Environment and Food Security. 4; 2002. Available from: http://www.fao.org/docrep/005/ Y4137E/y4137e00.htm\#TopOfPage.

[6] Ghosh B, Bhat R. Environmental Hazards of Nitrogen Loading in Wetland Rice Fields. In: Nitrogen, the Confer-Ns. Elsevier; 1998. pp. 123-126. doi:10.1016/C2009-0-07747-2.

[7] Asaduzzaman M. Resource Degradation and Sustainable Development in Bangladesh: Some Preliminary Estimates. Paper presented in seminar on planning for sustainable development of Bangladesh., Dhaka, Bangladesh. becoming more aware of environment and health issues.

Based on the findings of this study, several policy recommendations can be made. Firstly, since this study emphasizes the increase in consumers' income levels, initiatives that promote Bangladesh becoming a middle-income nation should be pursued, encouraged and supported. Secondly, it is necessary to create policies that will provide incentives, such as subsidies, to farmers to follow more organic agricultural practices [20]. Campaigns to increase demand for organically produced crops would help to attract consumers towards organic products, and would thereby increase both the market prices of these products and farmers' willingness to adopt organic farming methods. Thirdly, the quality and authenticity of organic products should be ensured. The government should play the leading role here, and there could be consumer bodies/unions created to keep track of the process. 'Certifying bodies' could also be established in this regard, which would have the authority to label organic products as 'Certified Organics', i.e. as produced according to the organic standards set by and certified by certifying bodies [23]. Fourthly, facilities should be provided to existing organic producers to be able to market their crops more easily and efficiently. Lastly, training and knowledgesharing opportunities (e.g. organic food production training programs and integrated pest management training) should be provided to farmers to learn about organic farming.

Food security has been a priority for Bangladesh for a long time. The time is approaching, for the sake of saving our environment, for greener farming methods to become our utmost priority. The findings of this study give us hope to look forward to a future where organic farming will become more feasible through the country progressing into a middle-income country.

[8] Hossain S, Salam M, Alam A. Farm Environment Assessment in the Context of Farming Systems in Bangladesh. Paper Presented in the third Asian Farming Systems Symposium.

[9] Hossain S, Kashem M. Agronomic Management to Combat Declining Soil Fertility in Bangladesh. In: $6^{\text {th }}$ Biennial Conference of the Bangladesh Society of Agronomy, held on. vol. 29; 1997.

[10] Rahman S, Thapa GB. Environmental Impacts of Technological Change in Bangladesh Agriculture: Farmers' Perceptions and Empirical Evidence. Outlook on Agriculture. 1999;28(4):233-238. doi:10.1177/003072709902800406.

[11] Rahman S. Environmental Impacts of Modern Agricultural Technology Diffusion in Bangladesh: An Analysis of Farmers' Perceptions and their Determinants. Journal of Environmental Management. 2003;68(2):183-191. doi:10.1016/S0301-4797(03)00066-5.

[12] Biswas MR. Agriculture and Environment: A review, 1972-1992. Ambio. 1994;pp. 192-197. Available from: https://www.jstor.org/stable/ 4314198.

[13] Edwards CA. The Importance of Integration in Sustainable Agricultural Systems. Agriculture, ecosystems \& environment. 1989;27(14):25-35. doi:10.1016/0167-8809(89)90069-8.

[14] Dwyer M, Kubena L, Harvey R, Mayura K, Sarr A, Buckley S, et al. Effects of Inorganic Adsorbents and Cyclopiazonic Acid in Broiler Chickens. Poultry Science. 1997;76(8):1141-1149. doi:10.1093/ps/76.8.1141.

[15] Newcombe CP, MacDonald DD. Effects of Suspended Sediments on Aquatic Ecosystems. North American journal of fisheries management. 1991;11(1):72-82. doi:10.1577/15488675(1991)011;0072:EOSSOA ¿2.3.CO;2. 
[16] Heath A. Water Pollution and Fish Physiology. vol. 359. CRC. Press; 1995.

[17] Hansen JW. Is Agricultural Sustainability a Useful Concept? Agricultural Systems. 1996;50(2):117-143. doi:10.1016/0308521X(95)00011-S.

[18] Yunlong C, Smit B. Sustainability in Agriculture: A General Review. Agriculture, ecosystems \& environment. 1994;49(3):299-307. doi:10.1016/0167-8809(94)90059-0.

[19] Akter N. Alternative Agriculture in Bangladesh: A Study of UBINIG, CDA, and PROSHIKA Programmes. 1997; Available from: http://dspace.bracu.ac.bd/xmlui/bitstream/handle/10361/ 13223/Alternative\%20agriculture\%20in\%20Bangladesh\%20a\% 20study\%20of\%20UBINIG\%20CDA\%20\%20and\%20PROSHIKA\% 20Programmes. pdf? sequence $=1$ \&is Allowed $=y$.

[20] Rasul G, Thapa GB. Sustainability of Ecological and Conventional Agricultural Systems in Bangladesh: An Assessment Based on Environmental, Economic and Social Perspectives. Agricultural systems. 2004;79(3):327-351. doi:10.1016/S0308-521X(03)00090-8.

[21] IFOAM. IFOAM Annual Report; 2006. Available from: http://www. ifoam.bio/sites/default/files/page/files/ifoam_annual_report_20052006.pdf.

[22] Barański M, Średnicka-Tober D, Volakakis N, Seal C, Sanderson R, Stewart GB, et al. Higher Antioxidant and Lower Cadmium Concentrations and Lower Incidence of Pesticide Residues in Organically Grown Crops: A Systematic Literature Review and Meta-analyses. British Journal of Nutrition. 2014;112(5):794-811. doi:10.1017/S0007114514001366.

[23] Martin H. Introduction to Organic Farming. 2009;Available from: http: //www.omafra.gov.on.ca/english/crops/facts/09-077.htm\#define.

[24] DEFRA. Retrieved 2018, from GOV.UK;Department for Environment, Food \& Rural Affairs. Available from: https://www.gov.uk/government/ organisations/department-for-environment-food-rural-affairs. Department for Environment, Food \& Rural Affairs.

[25] Hossain M. Nature and Impact of the Green Revolution in Bangladesh. International Food Policy Research Institute; 1988. Available from: https://www.ifpri.org/publication/nature-and-impactgreen-revolution-bangladesh\#.

[26] Sattar M, Mian J. Agrochemicals: Their Effects on Crop Yields and Soil Properties. In: Seminar of Soil Scientist Association on Land Degradation and Soil Pollution; 1999. .

[27] Steila D, Pond TE. The Geography of Soils: Formation, Distribution, and Management. Rowman \& Littlefield; 1989.

[28] IFOAM. IFOAM Annual Report. Status of Global Organic Market Scenario; 2010. Available from: http://www.ifoam.bio/sites/default/ files/page/files/ifoam_annual_report_2010.pdf.

[29] Willer H, Yussefi M. The World of Organic Agriculture 2005-Statistics and Emerging Trends.

[30] IRRI. Golden Rice. Available from: http://irri.org/golden-rice.

[31] Qaim M, Kouser S. Genetically Modified Crops and Food Security. PloS one. 2013;8(6). doi:10.1371/journal.pone.0064879.

[32] Whitman DB. Genetically Modified Foods: Harmful or Helpful? CSA Discovery Guides. 2000;pp. 1-13. Available from: http://artsci.ucla. edu/biotech177/reading/GMO_Harm_or_Help.pdf.

[33] Capone R, Bilali HE, Debs P, Cardone G, Driouech N. Food System Sustainability and Food Security: Connecting the Dots. Journal of Food Security. 2014;2(1):13-22. doi:10.12691/jfs-2-1-2.

[34] Rahman M, Alam M. Risk Assessment of Pesticides used in Bangladesh. Journal of Civil Engineering. 1997;25(1):97-106. doi:10.1016/j.scitotenv.2016.06.014.

[35] Shamonti S. Reasons Behind Slow Growth of Organic Food Market in Bangladesh. R. Murshed, Interviewer.

[36] Whelan J, Msefer K, Chung CV. Economic Supply \& Demand. MIT; 2001. Available from: https://books.google.com/books?id=MnjZwEACAAJ.

[37] DM. 10 Reasons Organic Food is so Expensive. Available from: http://www.foxnews.com/food-drink/2012/03/11/10-reasonsorganic-food-is-so-expensive.html.

[38] WB. GDP per capita (USD). Retrieved July 23, 2019. Available from: https://data.worldbank.org/country/Bangladesh.

[39] Hughner RS, McDonagh P, Prothero A, Shultz CJ, Stanton J. Who are Organic Food Consumers? A Compilation and Review of Why People Purchase Organic Food. Journal of Consumer Behaviour: An International Research Review. 2007;6(2-3):94-110. doi:10.1002/cb.210.

[40] Shafie FA, Rennie D. Consumer Perceptions Towards Organic Food. Procedia-Social and Behavioral Sciences. 2012;49:360-367. doi:10.1016/j.sbspro.2012.07.034.

[41] Yiridoe EK, Bonti-Ankomah S, Martin RC. Comparison of Consumer Perceptions and Preference toward Organic versus Conventionally Produced Foods: A Review and Update of the Literature. Renewable Agriculture and Food Systems. 2005;20(4):193-205. doi:10.1079/RAF2005113.

[42] Sarker MA, Itohara Y, et al. Organic Farming and Poverty Elimination: A Suggested Model for Bangladesh. Journal of Organic Systems. 2008;3(1):68-79. Available from: https://www.organicsystems.org/journal/Vol_3(1)/pdf/68-80\%20Sarker.pdf.

[43] Raffaele Z, Simona N. Consumer Motivations in the Purchase of Organic Food. A Means-end Approach. British Food Journal. 2002;104(8):643-653. doi:10.1108/00070700210425930.

[44] Melitz MJ, Ottaviano Gl. Market Size, Trade, and Productivity. The Review of Economic Studies. 2008;75(1):295-316. doi:10.3386/w11393. 
Table A1. Age distribution of the consumers.

\begin{tabular}{llll}
\hline Consumer's Characteristics & $\begin{array}{l}\text { Distribution of the consumers based } \\
\text { on their characteristics }\end{array}$ & $\begin{array}{l}\text { Number of consumers } \\
(\mathbf{n = 1 2 0})\end{array}$ & $\begin{array}{l}\text { Percentage of } \\
\text { consumers }\end{array}$ \\
\hline \multirow{3}{*}{ Age (years) } & Young (below 35) & 43 & $35.83 \%$ \\
& Middle aged (36-50) & 66 & $55 \%$ \\
& Old (above 50) & 11 & $9.166 \%$ \\
\hline
\end{tabular}

Table A2. Occupation distribution of the consumers.

\begin{tabular}{ll}
\hline Occupation types & Number of respondents in each occupation $(\mathbf{n}=\mathbf{1 2 0})$ \\
\hline Non-government services & 39 \\
Government services & 11 \\
Business & 30 \\
Students & 36 \\
Housewife & 4 \\
\hline
\end{tabular}

Table A3. Educational levels of consumers.

\begin{tabular}{ll}
\hline Education level & $\begin{array}{l}\text { Number of respondents having studied up to each education } \\
\text { level }(\mathbf{n}=\mathbf{1 2 0})\end{array}$ \\
\hline Up to SSC & 9 \\
SSC passed & 11 \\
HSC passed & 16 \\
Under-graduate & 32 \\
Post-graduate & 54 \\
\hline
\end{tabular}

